\title{
Depth and temperature preferences of the deepwater flatfish Greenland halibut Reinhardtius hippoglossoides in an Arctic marine ecosystem
}

\author{
Iva Peklova ${ }^{1}$, Nigel E. Hussey ${ }^{1, *}$, Kevin J. Hedges ${ }^{2}$, Margaret A. Treble ${ }^{2}$, \\ Aaron T. Fisk ${ }^{1}$
}

${ }^{1}$ Great Lakes Institute for Environmental Research, University of Windsor, Windsor, Ontario N9B 3P4, Canada ${ }^{2}$ Fisheries and Oceans Canada, Winnipeg, Manitoba R3T 2N6, Canada

\begin{abstract}
Little is known about the movement of Arctic marine fish, particularly benthic species, despite growing pressure from commercial fisheries and a changing climate. The Greenland halibut Reinhardtius hippoglossoides lives in the deep, cold waters of the Arctic, North Atlantic and Pacific Oceans where it represents an important commercial fish species and a significant prey resource for whales and sharks. To investigate movement, depth and temperature preferences of Greenland halibut, 9 large (83 to $95 \mathrm{~cm}$ fork length) individuals were tagged with pop-off archival transmitting tags in Cumberland Sound, Baffin Island in August 2010 to record data for 70,100 and $300 \mathrm{~d}$. While all tags reported back, 7 tags provided the bulk of the data, transmitting (mean \pm SD) $67 \pm 7 \%$ of the data collected. Greenland halibut exhibited strong site fidelity to localised deep areas (900 to $1400 \mathrm{~m}$ ), but ranged between 400 and $1400 \mathrm{~m}$, with all tags poppingoff within $27 \mathrm{~km}$ of the tagging location. Mean depth was $1048 \pm 112 \mathrm{~m}(\mathrm{n}=7)$ during the ice-free season and $823 \pm 121 \mathrm{~m}(\mathrm{n}=2)$ during the ice-covered season. Temperature occupied by Greenland halibut from August until June ranged from 1.3 to $2.7^{\circ} \mathrm{C}$ (mean $\pm \mathrm{SD}: 2.2 \pm 0.01^{\circ} \mathrm{C}$ ). A mixedeffect model found preferred depth did not vary within a diel cycle, but did change among months. Seasonal movements coincided with ice cover, but further work is needed to clarify this relationship and determine the extent and timing of these movements within and beyond Cumberland Sound.
\end{abstract}

KEY WORDS: Arctic $\cdot$ Movement patterns $\cdot$ Archival tags $\cdot$ Marine fish $\cdot$ Depth preferences Sea ice

\section{INTRODUCTION}

Much of the Arctic has been protected from major exploitation by commercial fisheries because of the climate and the extent of sea ice, which have also likely contributed to the lack of movement and behavioural studies on Arctic marine fish species. The reduction in sea ice and the increase in temperature in polar regions that have occurred over the past 2 decades (Serreze et al. 2000, Rayner et al. 2003), along with global declines in temperate and tropical commercial fish stocks (Botsford et al. 1997, Christensen et al. 2003, Hilborn et al. 2003), have resulted in a growing interest in Arctic resources and an associated increase in commercial fishing pressure on Arctic marine fishes in seasonally icecovered areas (Schrank 2007). Limited knowledge on the movement of Arctic fishes is of concern given the additional stressors that are now having an impact on fish populations, namely changes in water temperature and ocean currents caused by climate change and the potential effects on the movement patterns of 
marine fishes, e.g. distribution and maturation of larvae (Gibson 1997, Sohn et al. 2010). Understanding how the characteristics of Arctic marine ecosystems relate to fish movement patterns (i.e. linking environmental parameters with the distribution and abundance of fishing resources) is of critical importance for the management and conservation of Arctic marine fish stocks (Schick et al. 2008).

Satellite telemetry has been used to study the movement, behaviour and environmental preferences of a wide range of aquatic species, including sharks (Sims et al. 2003, 2008, Teo et al. 2004, Brunnschweiler et al. 2010) and many teleostei, such as tuna (Block et al. 2001, Kitagawa et al. 2004, Schaefer \& Fuller 2004) and flatfishes (Seitz et al. 2003, Loher \& Seitz 2006, Loher \& Blood 2009). These tags are attached externally to the fish, during which time they record depth, temperature and light, and release after a specified length of time, thus providing insight into horizontal and vertical movements and habitat use over different spatial and temporal scales (Block et al. 2001, Wearmouth \& Sims 2009, Humphries et al. 2010). There is no requirement to recapture tagged individuals, making this technology particularly useful for studying fish in deepwater habitats and extreme environments, such as the Arctic, where daily fieldwork or observations are impractical. Despite the apparent advantages of this technology, it has been little used in such environments to date. The Greenland halibut Reinhardtius hippoglossoides has become an important commercial fish species, particularly in the Northwest Atlantic (Bowering \& Brodie 1995, DFO 2008a). This benthic flatfish inhabits deep (typically 400 to $1000 \mathrm{~m}$ and as deep as $2200 \mathrm{~m}$ ) (Vis et al. 1997, Bowering \& Nedreaas 2000) and cold $\left(\sim 0\right.$ to $\left.6^{\circ} \mathrm{C}\right)$ (Bowering \& Nedreaas 2000) waters in northern latitudes $\left(>45^{\circ} \mathrm{N}\right)$ in the Arctic, Atlantic and Pacific Oceans (Bowering 1984, Dyck et al. 2007). Older fish usually move to greater depths, where they spawn (Bristow 1992, Gundersen et al. 2010). The Greenland halibut feeds on a variety of species (Bowering \& Lilly 1992, Pedersen \& Riget 1993) and its diet changes with fish size, water depth and latitude of occurrence (Orr \& Bowering 1997). Despite being a flatfish, the Greenland halibut probably feeds on fast swimming pelagic organisms, such as capelin Mallotus villosus (Dennard et al. 2009) and cephalopods (Pedersen \& Riget 1993, Dawe et al.1998). The Greenland halibut is also an important prey item for key predators in Arctic food webs, including whales and the Greenland shark Somniosus microcephalus (Crawford 1992, Fisk et al. 2002, Laidre et al. 2004). Among flatfish species, the Greenland halibut is considered to be an exceptional swimmer (de Groot 1970, Anonymous 1993) and highly migratory; a recaptured T-bar anchor-tagged Greenland halibut travelled a straight line distance of $2500 \mathrm{~km}$ over 2 yr (Boje 2002).

Cumberland Sound is a large inlet located on the southeastern side of Baffin Island, Canada with bottom topography of shallow margins surrounding a deep central basin that descends to $\sim 1500$ m (Dennard et al. 2010). Typically, seasonal land-fast ice forms in the Sound, dividing the year into 2 major periods: ice covered (winter), when the Sound is predominantly covered with land-fast or drifting pack ice, and ice free (summer). These 2 periods have dictated 2 fishing seasons for Greenland halibut, a traditional winter fishery through the sea ice and the newly developed summer vessel-based fishery that operates in open water. The winter fishery is dependent on land-fast sea ice forming a stable platform on which to base fishing camps (DFO 2008b). Nearshore areas of Cumberland Sound that are typically covered by land-fast sea ice are characterized by having uneven bottom habitats with shallow areas $(<300 \mathrm{~m})$ that are interspersed with medium depth areas (350 to $700 \mathrm{~m}$ ) (DFO 2008b). Greenland halibut seem to be most abundant in a few of these medium depth areas (Pike 1994). Efforts to locate commercial concentrations of Greenland halibut in shallow locations (350 to $500 \mathrm{~m}$ ) on the winter fishing grounds during the summer open water period have not been successful. However, fishing has been good in the summer in deeper areas $(>700 \mathrm{~m})$ within the central portion of Cumberland Sound (Young 2010). These observations have led to speculation that the distribution of Greenland halibut within the Sound may vary across seasons.

We hypothesize that Greenland halibut move from the deep water area into shallower habitats with the onset of colder temperatures and sea ice formation. Given evidence of pelagic feeding (Dennard et al. 2009), the species is also hypothesized to show rapid and regular vertical movements into the water column following the normal diel vertical migration of zooplankton and potential pelagic prey species such as capelin (Bailey et al. 1977, Davoren et al. 2006). To quantify the vertical movement patterns and temperature preferences of Greenland halibut in Cumberland Sound, Baffin Island, 9 large fish were tagged with pop-off archival transmitting (PAT) tags (MiniPAT, Wildlife Computers) in August 2010. The distribution of archival tag pop-off locations, the bathymetry of Cumberland Sound, and the timing of ice cover were used to identify seasonal horizontal movement 
patterns and site fidelity of this species. The performance of MiniPAT tags attached to Greenland halibut and exposed to unique depths (up to $1400 \mathrm{~m}$ ) and extreme environmental conditions is summarized.

\section{MATERIALS AND METHODS}

\section{Study sites and tag attachment}

Tagging of fish was carried out on 17 August 2010 in the deepwater region in central Cumberland Sound, Baffin Island, Canada $\left(65.659^{\circ} \mathrm{N}, 65.851^{\circ} \mathrm{W}\right.$; Fig. 1). All fish were captured using bottom longlines set at $\sim 900$ to $1100 \mathrm{~m}$ water depth. Each longline was $\sim 1900 \mathrm{~m}$ in length, with 1500 to 2000 gangions of $1 \mathrm{~m}$ with Mustad's Duratin Tuna Circle (O. Mustad \& Son) and hook sizes 15 and 16, baited with frozen squid and soaked for $\sim 12 \mathrm{~h}$. Longlines were pulled to the surface and fish were gently unhooked and fork length (FL) recorded. In order to successfully retain the tag with minimal effect on the fish's behaviour, the largest individuals (over $80 \mathrm{~cm} \mathrm{FL}$ ) that had no apparent injuries were chosen for tagging. Each tagging procedure took $\sim 3$ to $4 \mathrm{~min}$, following which each tagged fish was kept onboard in a sea water holding tank for 15 min to verify that the tagging was successful and the animal was healthy prior to release. Tags were attached externally to the eyeside of Greenland halibut using a titanium dart and a $15 \mathrm{~cm}$ tether (300 lb test monofilament with stainless steel Nicopress sleeves), following the methods of Loher \& Seitz (2006) and Loher (2008). The wire and sleeves were covered with polyolefin shrink to minimise the irritation and abrasion of tissue. The dart was inserted below the dorsal set of pterygiophores, within the deepest section of muscle tissue ( $T$. Loher pers. comm.).

\section{Tag model and set up}

Wildlife Computers pop-off archival transmitting (MiniPAT) tags were preset to record both depth and ambient temperature at time intervals of 150, 300 and $600 \mathrm{~s}$ and were deployed for 70 (August 2010 to October 2010), 100 (August 2010 to November 2010), and $300 \mathrm{~d}$ (August 2010 to June 2011), respectively; deployment times and data collection reflected the memory capacity of the tags. Short deployment periods provided the highest resolution data on depth and temperature profiles to provide insight into detailed vertical behavioural patterns, whereas longer deployments provided data on longer-term

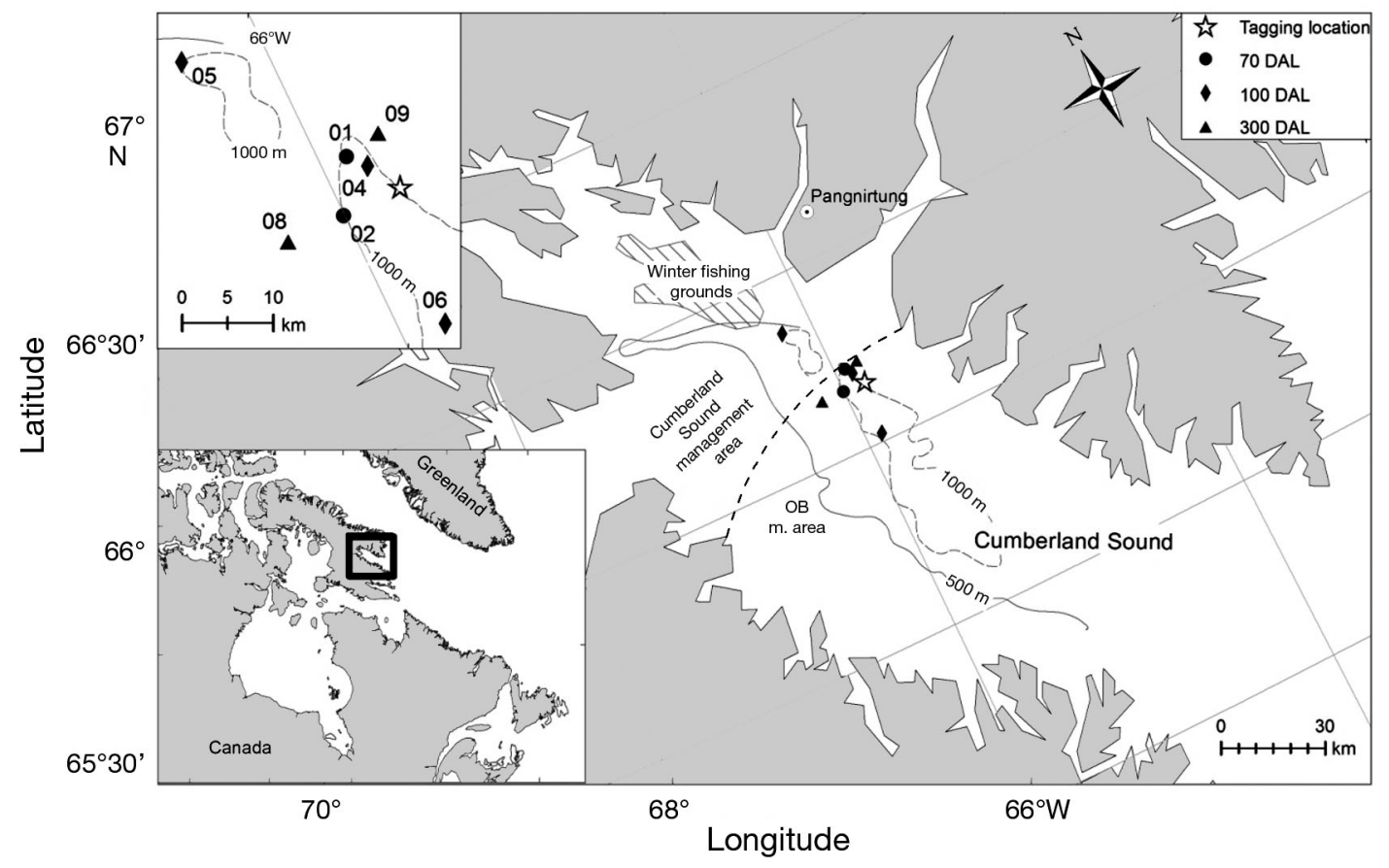

Fig. 1. Reinhardtius hippoglossoides. Tagging and pop-off locations (labelled in inset with fish numbers 01-09) for 70, 100 and $300 \mathrm{~d}$ at liberty (DAL) deployments for Greenland halibut $(\mathrm{n}=7)$ tagged in August 2010 in Cumberland Sound, Baffin Island. Deep water area $(>1000 \mathrm{~m})$ corresponds to summer fishery grounds. Contour lines $(500,1000 \mathrm{~m})$ are shown. Hatched area represents winter fishing grounds; bold dashed line: boundary between Cumberland Sound and Division 0B management areas 
Table 1. Reinhardtius hippoglossoides. Biological and pop-off archival transmitting (MiniPAT) tag data for Greenland halibut tagged in Cumberland Sound (65.659 ${ }^{\circ} \mathrm{N}$ and $\left.65.851^{\circ} \mathrm{W}\right)$ on 17 August 2010. Percent depth and temperature (temp.) data reported were determined from actual count of readings divided by the maximum count of readings within the deployment period

\begin{tabular}{|c|c|c|c|c|c|c|c|c|c|c|c|c|}
\hline \multirow{2}{*}{$\begin{array}{l}\text { Fish } \\
\text { ID }\end{array}$} & \multirow{2}{*}{$\begin{array}{l}\text { Fork } \\
\text { length } \\
(\mathrm{cm})\end{array}$} & \multirow{2}{*}{$\begin{array}{c}\text { Programmed } \\
\text { pop-off } \\
\text { date }\end{array}$} & \multirow{2}{*}{$\begin{array}{l}\text { Actual } \\
\text { pop-off } \\
\text { date }\end{array}$} & \multirow{2}{*}{$\begin{array}{c}\text { Sampling } \\
\text { interval } \\
\text { (s) }\end{array}$} & \multirow{2}{*}{$\begin{array}{l}\text { Days } \\
\text { at } \\
\text { liberty }\end{array}$} & \multicolumn{2}{|c|}{ Depth data } & \multicolumn{2}{|c|}{ Temp. data } & \multicolumn{2}{|c|}{ Pop-off } & \multirow{2}{*}{$\begin{array}{c}\text { Distance } \\
\text { travelled } \\
(\mathrm{km})\end{array}$} \\
\hline & & & & & & $\begin{array}{l}\text { No. of } \\
\text { days }\end{array}$ & $\begin{array}{c}\% \\
\text { reported }\end{array}$ & $\begin{array}{c}\text { No. of } \\
\text { days }\end{array}$ & $\begin{array}{c}\% \\
\text { reported }\end{array}$ & $\begin{array}{c}\text { latitude } \\
\left({ }^{\circ} \mathrm{N}\right)\end{array}$ & $\begin{array}{c}\text { longitude } \\
\left({ }^{\circ} \mathrm{W}\right)\end{array}$ & \\
\hline 01 & 84 & 26 Oct 10 & 29 Oct 10 & 150 & 70 & 45.1 & 64.0 & 44.7 & 63.4 & 65.708 & 65.935 & 6.7 \\
\hline 02 & 85 & 26 Oct 10 & 27 Oct 10 & 150 & 70 & 50.1 & 71.1 & 48.4 & 68.8 & 65.658 & 66.003 & 3.4 \\
\hline $03^{\mathrm{a}}$ & 85 & 26 Oct 10 & 7 Nov 10 & 150 & 84 & 0 & - & 0 & - & - & - & - \\
\hline 04 & 95 & 25 Nov 10 & 26 Nov 10 & 300 & 101 & 59.5 & 58.8 & 58.3 & 57.6 & 65.691 & 65.899 & 3.2 \\
\hline 05 & 90 & 25 Nov 10 & 26 Nov 10 & 300 & 101 & 58.0 & 57.6 & 52.7 & 52.3 & 65.859 & 66.197 & 27.4 \\
\hline 06 & 88 & 25 Nov 10 & 26 Nov 10 & 300 & 101 & 73.4 & 72.7 & 74.1 & 73.4 & 65.521 & 65.894 & 15.7 \\
\hline $07^{\mathrm{b}}$ & 93 & 13 Jun 11 & 24 Jun 11 & 600 & 310 & 27.7 & 74.4 & 26.3 & 75.7 & - & - & - \\
\hline 08 & 83 & 13 Jun 11 & 14 Jun 11 & 600 & 300 & 219.0 & 72.8 & 217.6 & 72.4 & 65.658 & 66.151 & 13.8 \\
\hline 09 & 92 & 13 Jun 11 & 14 Jun 11 & 600 & 300 & 216.2 & 71.9 & 208.9 & 69.4 & 65.715 & 65.843 & 6.3 \\
\hline All & & & & & & 748.9 & 67.9 & 731.1 & 66.6 & & & \\
\hline
\end{tabular}

behavioural patterns and movements. A total of 9 MiniPAT tags were placed on Greenland halibut (mean FL \pm SD: $88.8 \pm 4.4 \mathrm{~cm}$; Table 1); 3 tags were designated for each of the deployment periods. Premature release of the tag at constant depth was disabled because of the benthic nature of Greenland halibut and the expectation that periods of potentially minimal movement would occur.

\section{Data analysis}

All analyses were performed on time-series depth and temperature data sets that were transmitted by the tags via satellites. To summarise depth and tem- perature preferences, all data were pooled (i.e. data from all 70, 100, and $300 \mathrm{~d}$ deployments) into bins of $100 \mathrm{~m}(300$ to $1500 \mathrm{~m})$ for depth and by $0.5^{\circ} \mathrm{C}(0.0$ to $6.0^{\circ} \mathrm{C}$ ) for temperature to depict the main depth/temperature trends over the course of the tag deployment (Fig. 2). The relationship between the raw depth data, i.e. time-series depth data for each fish, and 3 major covariates was analysed using a linear mixed-effect model fit using restricted maximum likelihood in the lme4 package in R (Bates \& Maechler 2010, R Core Development Team 2012). The 3 covariates were (1) day/night, representing the light/ dark period of the day, derived from Nautical almanac at $66^{\circ} \mathrm{N}$ latitude (NavSoft 2010) and modelled as a fixed effect; (2) month (August to November, which is the approximate duration of the fishing season); and (3) individual fish ( $\mathrm{n}=5$, i.e. individuals within the deployment period of August to November), modelled as a crossed random effect. An examination of the probability plots of residuals from the model relating depth to day/night indicated adequate model fit, and quantile-quantile plots showed data to be generally described by normally distributed errors.

To estimate a downward swimming speed for Greenland halibut in the pelagic water column, data for the change in depth (as an approximation of distance) over time (the ini-
Fig. 2. Reinhardtius hippoglossoides. Depth and temperature preferences for Greenland halibut ( $\mathrm{n}=8$ ), combined over all 70, 100 and 300 days at liberty (DAL) deployments 


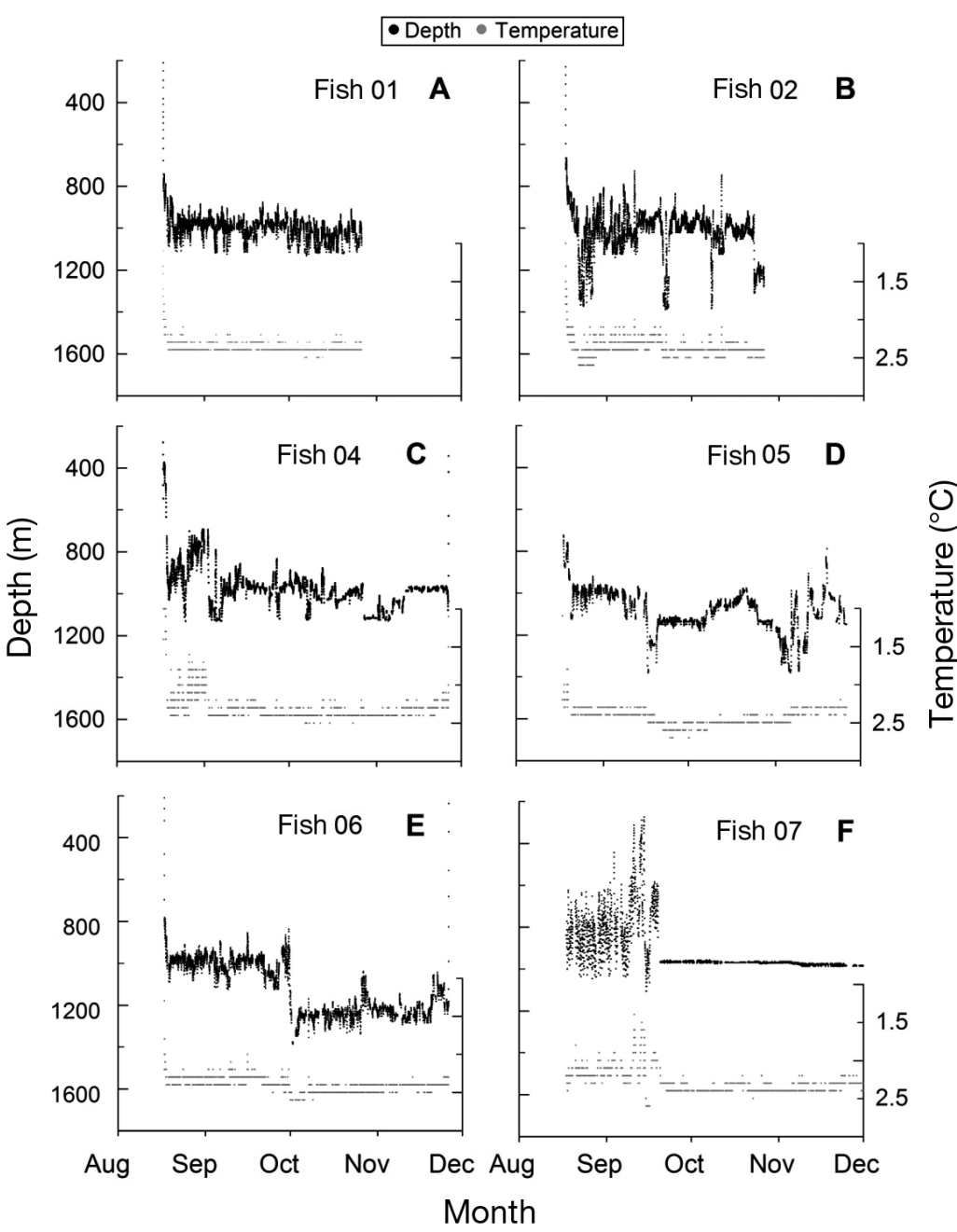

Fig. 3. Reinhardtius hippoglossoides. Individual depth and temperature profiles $(n=6)$ for 70 and $100 \mathrm{~d}$ deployments of tags attached to Greenland due to premature tag detachment from the fish or death of this individual halibut. Fish 07 reported a constant depth after 19 September 2010 possibly

above a flat plain or moved sideways at the same depth level. Swimming was assumed to be continuous if 2 consecutive depth observations showed changes in depth (i.e. fish were assumed not to rest for any portion of the sampling interval between 2 consecutive depth observations). Given that the above 2 described inaccuracies are embedded in these estimates, the calculated swimming speeds are considered to be a method of evaluating pelagic behaviour and do not represent actual swimming speeds.

\section{RESULTS}

\section{Functionality of the tags}

All of the tags deployed on Greenland halibut reported to Argos satellites within days of the programmed pop-off dates (mean $\pm \mathrm{SD}: 3.6 \pm 4.6 \mathrm{~d}$ after, range $=1$ to $12 \mathrm{~d}$ after) (Table 1$)$. None of the tags were physically retrieved. Two of the tags (those on Fish 03, 07) reported constant depths for 70 out of $70 \mathrm{~d}$ and 278 out of $300 \mathrm{~d}$ (constant depth after 19 September 2010), respectively, (Fig. 3) prior to the preprogrammed pop-off date. Consequently, only a portion of the archival data record collected from Fish 07 was analysed (from 17 August to 19 September 2010), and the record from Fish 03 was omitted from our analyses. Including the small portion of the record tial 10 min descent of the fish after it was tagged) were extracted. The initial descent was used because it was a guaranteed movement in the pelagic water column, thus an approximate estimate for the baseline swimming speed that a Greenland halibut can achieve in the pelagic water column. Swimming speeds for upward and downward movements within the natural depth range of Greenland halibut were estimated from randomly selected $10 \mathrm{~min}$ periods (30 periods movement ${ }^{-1}$ ) during which an individual made clear ascent or descent movement with apparent change in depth between each 2 consecutive observations. These speeds were then compared to the swimming speed of the initial descent in the pelagic water column. Swimming speeds calculated here captured distance as a 2-dimensional movement based on change in depth, and did not account for horizontal movements, e.g. when fish swam from Fish 07, the remaining 8 tags transmitted between 57.6 and $74.4 \%(67.9 \pm 6.8 \%)$ of their depth and 52.3 and $75.7 \%(66.6 \pm 8.2 \%)$ of their temperature records, yielding a total of 749 and $731 \mathrm{~d}$ of depth and temperature data, respectively (Table 1). Tags did not provide any light level data, which was consistent with the depths occupied by Greenland halibut.

\section{Pop-off positions}

All of the tags popped off in Cumberland Sound (Fig. 1) between 3.2 and $27.4 \mathrm{~km}(10 \pm 8.7 \mathrm{~km}$ ) from the tagging location (Fig. 1). All fish (except for Fish 06, which moved south of the tagging location) moved north, west or northwest from the tagging location (Fig. 1). Fish that were tagged in the same deployment period did not show any clear trends in 


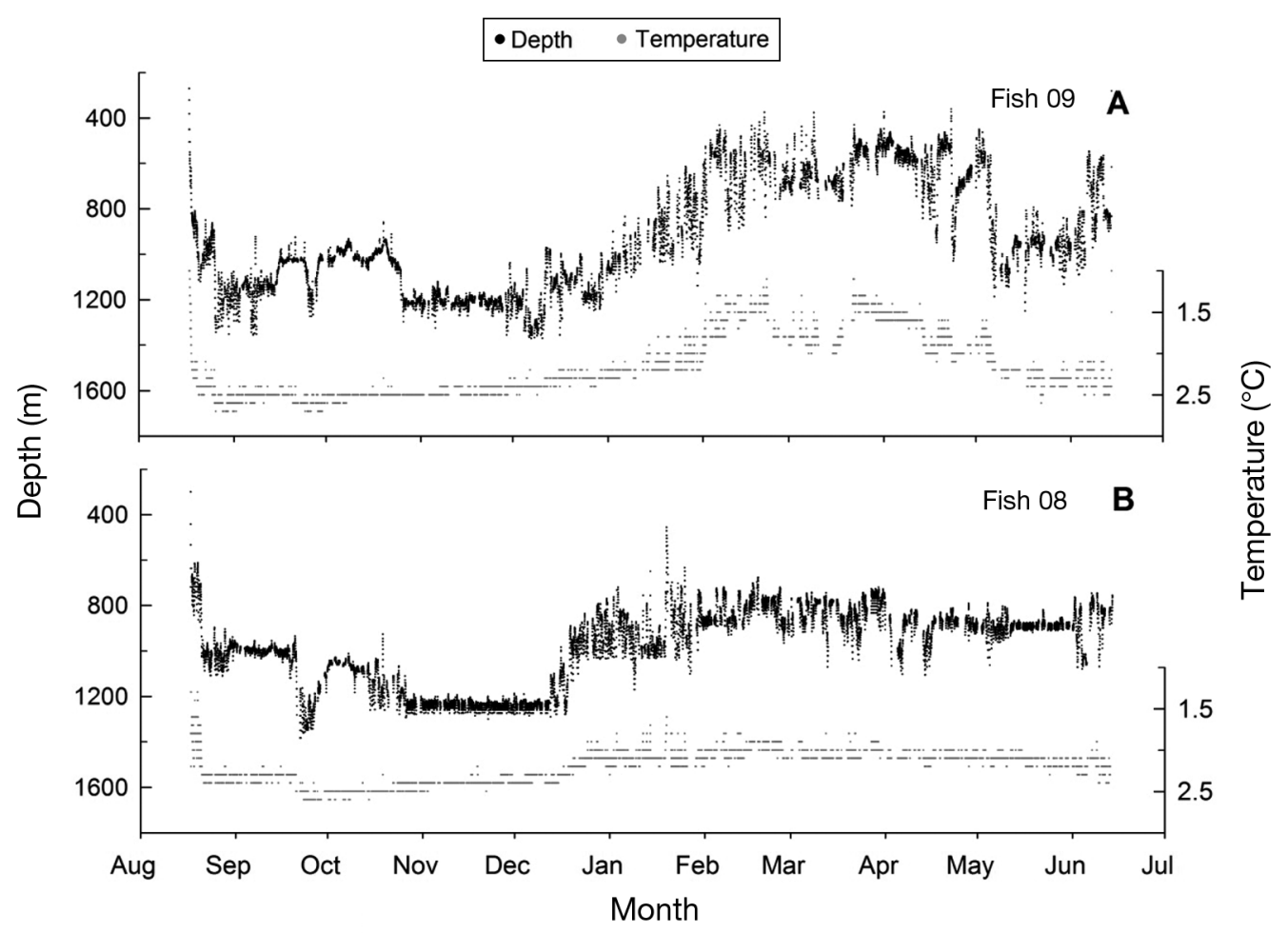

Fig. 4. Reinhardtius hippoglossoides. Individual Greenland halibut depth and temperature profiles $(\mathrm{n}=2)$ for $300 \mathrm{~d}$ tag deployments

direction of movement. Two fish that spent $100 \mathrm{~d}$ at liberty (DAL) (Fish 05, 06) moved the furthest distance from the tagging location, 27.4 and $15.7 \mathrm{~km}$, respectively. All 3 fish tags programmed for $300 \mathrm{DAL}$ (Fish 07, 08, 09) popped of within a $16 \mathrm{~km}$ radius of the tagging location (Fig.1). Because its tag reported constant depths after 19 September 2010, Fish 07 did not provide data for the ice-cover season. Depth profiles recorded from Fish 09 showed that this fish occupied shallower waters $(<600 \mathrm{~m})$ during the winter (Fig. 4). If the fish moved to winter fishery areas (assuming that these movements were tied to the bathymetry of Cumberland Sound and were not a result of the fish swimming in the pelagic water column), this would mean the fish travelled at least $50 \mathrm{~km}$ during its time at liberty. However, we cannot exclude the possibility that the fish moved to the shallower waters surrounding this area.

\section{Depth and temperature preferences}

Greenland halibut $(\mathrm{n}=7$ ) ranged between $\sim 400$ and $1400 \mathrm{~m}$ depth but spent $89 \%$ of the DAL below $900 \mathrm{~m}$ (Fig. 2). Depth preferences changed over the course of the year; Greenland halibut occupied deeper waters from August to December (1047 \pm
$112 \mathrm{~m} ; \mathrm{n}=7$ ) and then moved to shallower waters between January and June $(823 \pm 121 \mathrm{~m}$; Fig. 5), although data for January to June included only 2 fish. Results of the model, used to describe the relationship between depth and day/night, were not significant $(t<-2$; Table 2$)$. The negligible difference from the overall intercept (mean level of depth was $1076 \mathrm{~m}$, Table 2) associated with the day/night variable $(-1.287$; Table 2$)$ and the weak correlation

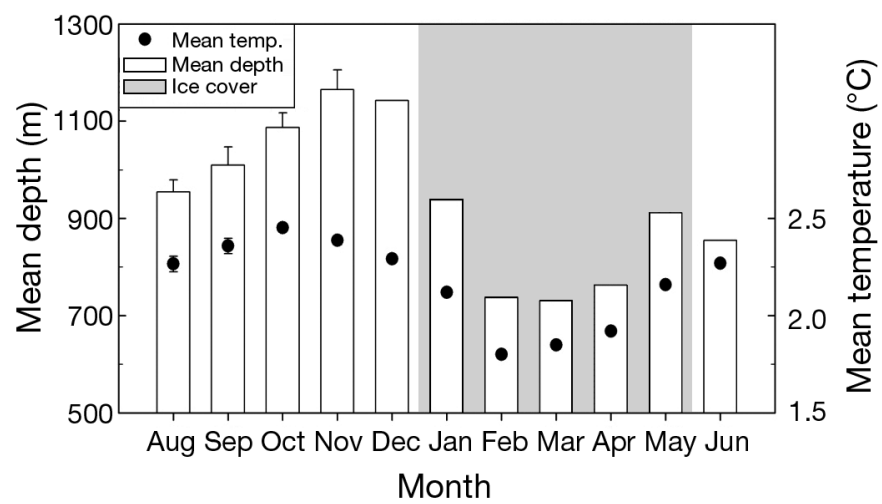

Fig. 5. Reinhardtius hippoglossoides. Monthly mean (+ SE) depth and mean $( \pm \mathrm{SE})$ temperature (temp.) preferences of Greenland halibut relative to presence of ice cover for August to October $2010(n=7)$, November $2010(n=5)$, and December 2010 to June 2011 ( $\mathrm{n}=2$ ) 
Table 2. Results of the mixed-effect model to describe the relationship between depth occupied by flatfish and 3 covariates. Individual fish and Month were treated as random variables, while Day/Night was included as a fixed covariate

\begin{tabular}{|lccc|}
\hline Random effects & Variance & \multicolumn{2}{c|}{ SD } \\
\hline Individual fish (intercept) & 3115.4 & 55.816 \\
Month (intercept) & 5194.6 & 72.073 \\
Residual & 7902.4 & 88.895 \\
No. of observations: 78869, & groups: Ind. fish 5, Month 4 \\
& Estimate & SE & $t$-value \\
Fixed effects & 1076.6243 & 43.8395 & 24.558 \\
(Intercept) & -1.2868 & 0.6589 & -1.953 \\
Day/Night & & & \\
Correlation of fixed effects: -0.008 & & \\
& & & \\
\end{tabular}

between the 2 variables $(-0.008$; Table 2$)$ indicated that there was no relationship between depth and day/night (Fig. 6), i.e. diel cycles were not important variables in explaining depth preferences. The variance attributed to individual fish was lower than the variance attributed to month (Table 2), indicating that month had a greater effect on depth preference. Residual variability was higher than both individual fish and month (Table 2), indicating greater within individual/month variation. A total of 5 out of 7 fish showed an overall trend towards inhabiting deeper waters from August to November, being at the deepest depth in November (Fig. 6). One fish that was tagged for $300 \mathrm{~d}$ (Fish 09) moved into shallower depths (ranging up to $361 \mathrm{~m}$ ) in January, returning to deeper waters in May (Table 3, Fig. 7A). A second fish that was tagged for $300 \mathrm{~d}$ (Fish 08) remained at greater depths throughout the tag deployment period except for a single excursion up to $457 \mathrm{~m}$ in

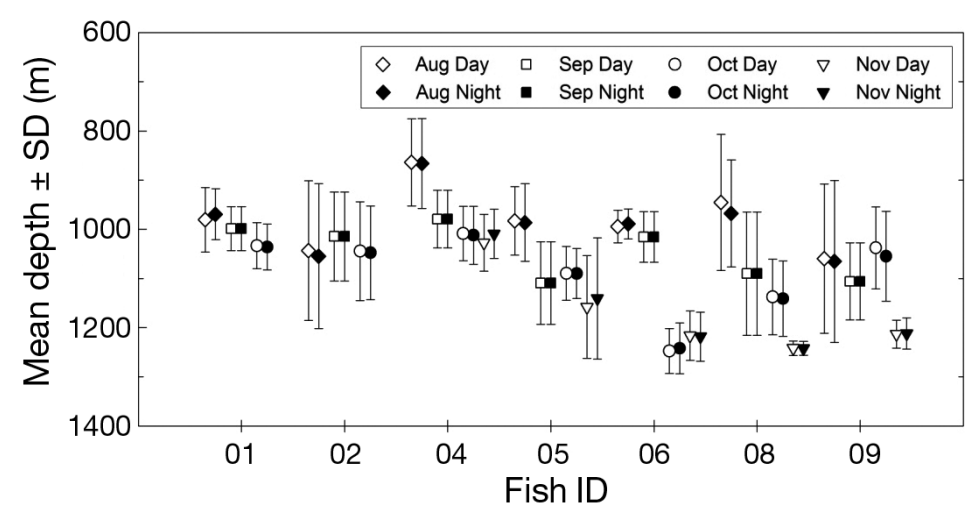

Fig. 6. Reinhardtius hippoglossoides. Mean depth $( \pm \mathrm{SD})$ for individual Greenland halibut during day and night for individual months (August to November)
January (Fig. 7B). Although Fish 08 did not inhabit the same depths as Fish 09 over the 300 d period, it did occupy shallower depths on average between January and June $(881 \pm 41 \mathrm{~m})$ compared to the August to December period $(1102 \pm 108 \mathrm{~m}$; Figs. 4B \& 7B).

Greenland halibut $(\mathrm{n}=7$ ) experienced temperatures between 1.3 and $2.7^{\circ} \mathrm{C}$ but spent $>85 \%$ of their days at 2.0 to $2.5^{\circ} \mathrm{C}$ (Table 3, Fig. 2). The temperature profiles from the tags varied over the course of the year. Between September and November fish occupied waters $>2.3^{\circ} \mathrm{C}$, whereas between February to April the mean temperature was 1.8 to $1.9^{\circ} \mathrm{C}$.

\section{Vertical activity and swimming speeds}

Detailed depth profiles revealed that Greenland halibut displayed a continuum of activity levels (from zero to moderate to high activity) that varied without any clear cyclic or temporal patterns (Figs. $3 \& 4$ ). The 2 ends of the activity continuum yielded 2 distinct behaviours, which were common to most of the tagged fish. The first behavioural type was characterised by long periods $(>1 \mathrm{~h}$ ) of zero or minimal change in depth, i.e. minimal activity. This behaviour was observed for all fish except one (Fish 07, Fig. 3F) and was randomly scattered throughout the timeseries depth records. The other end of the spectrum was defined by gradual upward and downward vertical movements, with typical short breaks ( $\sim 5$ to $30 \mathrm{~min}$ ) of no change in depth and an overall change in depth of $\sim 100$ to $300 \mathrm{~m} \mathrm{~h}^{-1}$. This behaviour was considered high activity and was observed over the steepest depth changes throughout the time-series depth profiles. This behaviour was typical for Fish 07

(Fig. 3F) and was observed throughout the duration of the time-series record $(30 \mathrm{~d})$. For the remaining fish the duration of this behaviour was anywhere from $1 \mathrm{~h}$ (e.g. Fish 02 and 08, Figs. 3B \& 4B, respectively) up to several days (e.g. Fish 09, Fig. 4A), but occurred less frequently. The majority of the time-series depth records of all fish consisted of up and down vertical movements with amplitudes ranging randomly between $\sim 10$ and $100 \mathrm{~m} \mathrm{~h}^{-1}$ with frequent short breaks ( $\sim$ to $30 \mathrm{~min}$ ).

Swimming speeds calculated for the randomly selected upward or downward movements ranged between 0.02 and $0.18 \mathrm{~m} \mathrm{~s}^{-1}$ for upward and 0.02 and $0.15 \mathrm{~m} \mathrm{~s}^{-1}$ for downward swimming (mean \pm SD: $0.08 \pm 0.01$ and $0.07 \pm 0.01 \mathrm{~m} \mathrm{~s}^{-1}$ for upward and downward swimming, respectively) 
Table 3. Reinhardtius hippoglossoides. Mean, minimum and maximum depth and temperature data, as well as swimming speed, for Greenland halibut monitored using pop-off archival transmitting (MiniPAT) tags in Cumberland Sound in 2010. Downward pelagic (down. pel.) swimming speed was determined from return to naturally occupied depths after being tagged. All mean values include SD in parentheses; up.: upward; down.: downward

\begin{tabular}{|c|c|c|c|c|c|c|c|c|c|c|}
\hline \multirow{2}{*}{$\begin{array}{l}\text { Fish } \\
\text { ID }\end{array}$} & \multirow{2}{*}{$\begin{array}{l}\text { Months } \\
\text { deployed }\end{array}$} & \multicolumn{3}{|c|}{$\longrightarrow$ Depth $(\mathrm{m})-$} & \multicolumn{3}{|c|}{ Temp. $\left({ }^{\circ} \mathrm{C}\right)-$} & \multicolumn{3}{|c|}{$\longrightarrow$ Swimming speed $\left(\mathrm{m} \mathrm{s}^{-1}\right)$} \\
\hline & & Mean & Min. & Max. & Mean & Min. & Max. & Down. pel. & Peak up. & Peak down. \\
\hline 01 & Aug-Oct & $1007(37)$ & 743.0 & 1132.5 & $2.37(0.07)$ & 1.8 & 2.5 & 0.25 & $0.07(0.01)$ & $0.04(0.01)$ \\
\hline 02 & Aug-Oct & $1033(99)$ & 727.0 & 1389.0 & $2.38(0.11)$ & 1.6 & 2.6 & 0.40 & $0.12(0.04)$ & $0.10(0.04)$ \\
\hline 03 & Aug-Oct & - & - & - & - & - & - & - & - & - \\
\hline 04 & Aug-Nov & 985 (77) & 693.0 & 1131.5 & $2.30(0.21)$ & 1.6 & 2.5 & 0.33 & $0.05(0.02)$ & $0.06(0.02)$ \\
\hline 05 & Aug-Nov & $1090(92)$ & 759.0 & 1380.0 & $2.41(0.17)$ & 1.8 & 2.7 & - & $0.08(0.03)$ & $0.06(0.03)$ \\
\hline 06 & Aug-Nov & 1131 (118) & 789.5 & 1386.0 & $2.40(0.08)$ & 2.0 & 2.6 & 0.36 & $0.08(0.02)$ & $0.10(0.04)$ \\
\hline $07^{\mathrm{a}}$ & Aug-Sep & 821 (137) & 274.0 & 1106.5 & $2.14(0.18)$ & 1.4 & 2.6 & - & - & - \\
\hline 08 & Aug-Jun & 998 (163) & 457.0 & 1383.5 & $2.21(0.19)$ & 1.3 & 2.6 & 0.18 & $0.07(0.02)$ & $0.05(0.01)$ \\
\hline 09 & Aug-Jun & $942(242)$ & 361.0 & 1370.5 & $2.19(0.36)$ & 1.3 & 2.7 & 0.24 & $0.07(0.02)$ & $0.06(0.02)$ \\
\hline All & & & & & & & & $0.29(0.08)$ & $0.08(0.01)$ & $0.07(0.01)$ \\
\hline
\end{tabular}

${ }^{a}$ Only data recorded between 17 August and 19 September 2010 were analysed

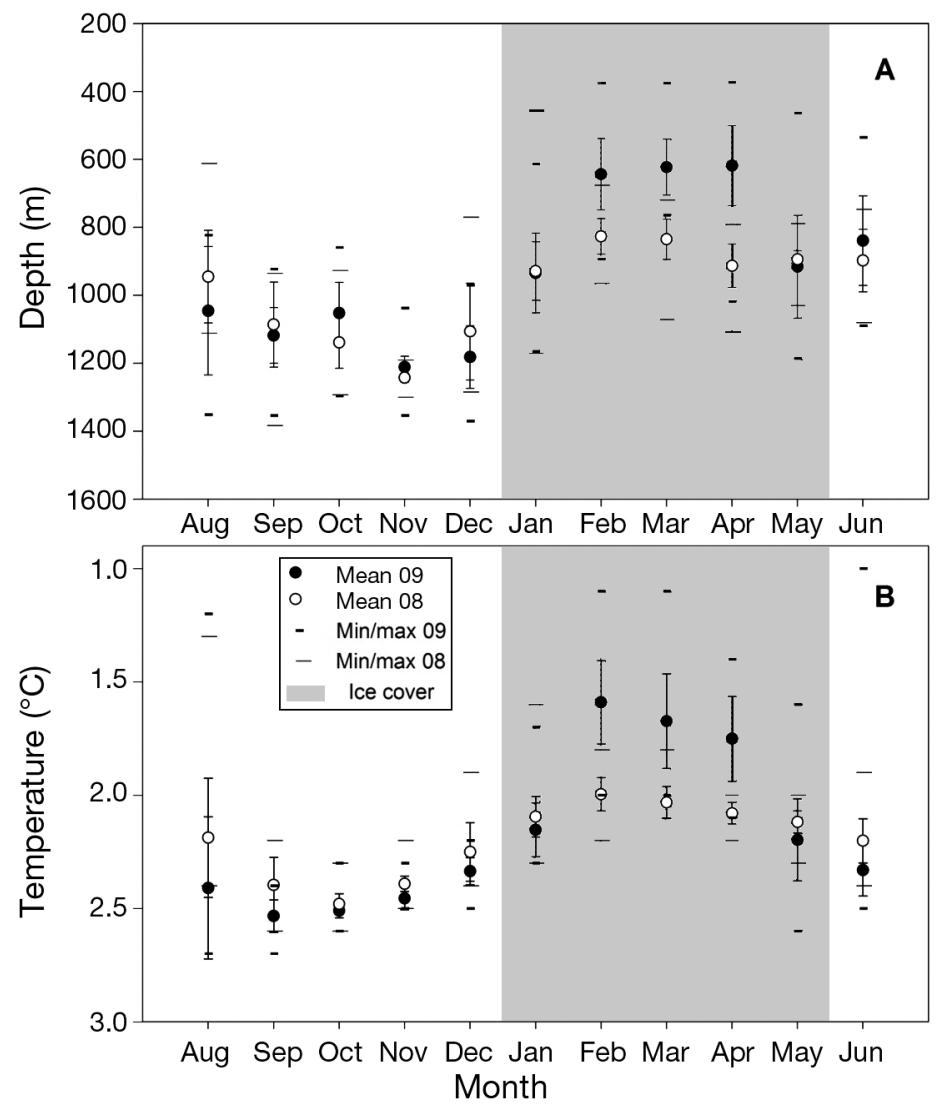

Fig. 7. Reinhardtius hippoglossoides. Monthly mean ( $\pm \mathrm{SD})$, minimum and maximum (A) depth (m) and (B) temperature $\left({ }^{\circ} \mathrm{C}\right)$ profiles for Fish 08 and 09 relative to complete ice cover (shaded area; Environment Canada archive; ice-glaces.ec.gc.ca) for August 2010 to June 2011. Depth profile for Fish 09 indicated a seasonal movement because the fish stayed in the deep water pocket during the ice-free period and moved to shallower waters for the ice covered season. The second fish (Fish 08) showed a less pronounced change in depth occupied with season, but still inhabited deeper waters during the ice-free period
(Table 3). The maximum swimming speed (which was thought to approximate pelagic swimming speed) obtained by Greenland halibut during their initial decent after tagging was $0.40 \mathrm{~m} \mathrm{~s}^{-1}\left(0.29 \pm 0.08 \mathrm{~m} \mathrm{~s}^{-1}, \mathrm{n}=6\right.$, Table 3$)$; however, these speeds might not reflect normal behaviour due to the effects of the tagging process and unnatural behaviour for Greenland halibut (i.e. they do not normally swim in a strictly vertical manner, Albert et al. 2012). Swimming speeds estimated for the high activity periods were typically lower than that of the initial descent, suggesting that rapid movements into the pelagic water column were scarce. Alternatively, Greenland halibut could enter the pelagic water column at lower swimming speeds than that of the initial descent.

\section{DISCUSSION}

Pop-off archival transmitting tag data found that Greenland halibut from Cumberland Sound showed a preference for deep (>900 m) and cold $\left(\sim 2.3^{\circ} \mathrm{C}\right)$ waters, but also indicated movement from the deep waters that were occupied during the ice-free season to shallower (and relatively colder) waters during the ice-covered season. Tagged Greenland halibut showed strong site fidelity for deepwater areas within the central part of the Sound from August to November, when most of the tags were programmed to pop off. This site fidelity in the deepwater area correlated with the preferred location of the summer commercial Greenland halibut fishery. 
Depth data from 2 fish that were at liberty for $300 \mathrm{~d}$, which included the ice-cover season, indicated that Greenland halibut were moving within the Sound during ice-covered periods and inhabited shallower depths. Although previous evidence has suggested that Greenland halibut feed on pelagic prey (Dennard et al. 2009), tagged Greenland halibut did not show any diel differences in depths, and rapid vertical movements into the water column were scarce.

\section{Tag performance}

All of the MiniPAT tags performed well in the extreme environmental conditions, experiencing temperatures as low as $-1.7^{\circ} \mathrm{C}$ and depths of $1400 \mathrm{~m}$. All 9 tags reported back (100\% report rate), a report rate that is $17 \%$ higher than the overall pop-off satellite archival transmitting (PSAT) report rate registered by the tag manufacturer, Wildlife Computers (Musyl et al. 2011). Seven tags remained attached until the programmed pop-off date (77.8\%) and returned $67 \%$ of the data on average. We found no difference in the rate of data return among tags that were logging different numbers of total messages. Tags that were deployed for the longest periods (i.e. 300 d) transmitted the largest portion of their total record, despite the higher total record size (3150, 1680 and 2058 messages for 300, 100 and 70 d, respectively). These data return rates may suggest that Arctic weather plays an important role in transmission success, with more favourable transmission conditions in late spring compared to early winter. Two tags (from Fish 03 and 07) reported a constant depth prior to release, but because these tags released at the pre-programmed date, this constant depth was likely not caused by tag malfunction. Rather, the tags recorded constant depth because either the fish died, remaining on the bottom, or the combined weight of the anchoring device including the dart and leader wire, coupled with the dense deep Arctic waters might have held the tag at depth until the link corroded (H. Baer pers. comm.). Given the high rate of scavenging in the Arctic, for example by the amphipod Anonyx nugax (Klages et al. 2002, Fisk et al. 2003), carcasses are unlikely to be missed; therefore the latter explanation is more likely.

\section{Depth preference}

Pop-off archival transmitting data indicated that large $(>80 \mathrm{~cm})$ Greenland halibut occupied any area of the Sound where depths were greater than $375 \mathrm{~m}$; the greatest depth experienced by a Greenland halibut ( 1400 m) matched the deepest depth known for Cumberland Sound. However, all of the fish preferred depths that were below $900 \mathrm{~m}$, which was expected because Greenland halibut are known to move to deeper waters as they mature (Atkinson \& Bowering 1987), preferring deepwater channels running between shallower banks (Bowering \& Nedreaas 2000). Multi-species fish surveys in Davis Strait found that larger Greenland halibut occurred at greater depths and population densities were highest between 750 and $1250 \mathrm{~m}$ (Treble \& Jørgensen 2002, Treble 2011). Although the sample size in this study was small ( $\mathrm{n}=2$ from January to June), the linear mixed-effect model found that depth preference varied between August and November, and further variation in depth preference was coincidental with the development of land-fast ice (December to June), with fish moving into shallower waters as the ice formed.

Detailed depth records showed that Greenland halibut exhibited 2 distinct types of vertical behavioural movement patterns. The 2 behavioural types were randomly interspersed in a continuum of moderate activity levels, and vertical movements varied in amplitude, frequency and slope, similar to the behaviour observed in Pacific halibut Hippoglossus stenolepis (Seitz et al. 2003). The first, low activity, behaviour likely indicated resting. A second distinct behaviour, high activity, consisted of longer vertical movements often interspersed with periods of no change in depth. This lack of change in depth could have resulted from resting on the bottom, gliding mid water, or the inaccuracy of the tag pressure sensor. The former explanation would appear to be the most plausible considering the diverse bottom topography of Cumberland Sound. Observed changes in depth (for the vast majority of cases) were therefore likely a result of the fish following the uneven topography of the bottom of the Sound. However, other movement behaviours cannot be ruled out and more complex biologging tags, for example accelerometer tags, would be required to resolve this point.

The vertical movement by Greenland halibut was not related to diel cycles, which is consistent with the results of stratified random bottom and pelagic surveys (Jørgensen 1997a). The estimated swimming speeds (steep ascents and descents) throughout the depth record were largely not indicative of rapid vertical movements into the pelagic water column potentially to feed as has been reported for Greenland halibut in the Northeast Atlantic (Vollen \& 
Albert 2007, Albert et al. 2012). Studies have reported fast swimming prey in Greenland halibut diets, including demersal fishes; in particular, redfish Sebastes sp., and capelin were identified as a major diet component of Greenland halibut in Cumberland Sound based on stable isotopes (Dennard et al. 2009). The occurrence of pelagic fishes in the diet of Greenland halibut might be explained by the flatfish feeding on pelagic fishes and invertebrates when they occupy shallower water (i.e. during the ice-covered period) and habitat overlap (Allen \& Smith 1988). Flatfish often use an ambush foraging strategy to capture prey (Gibson 2005); for example, Kawabe et al. (2004) observed rapid ambush movements of $\sim 40 \mathrm{~s}$ into the pelagic water column by Japanese flounder Paralichthys olivaceus to catch prey. Greenland halibut may undertake a similar strategy; however, the shortest sampling period interval used in this study (150 s) would likely not be able to identify such rapid foraging movements. Alternatively, Greenland halibut could scavenge pelagic fishes, such as capelin (also proposed in Bjelland et al. 2000), when mass die-offs occur following spawning events (Vilhjálmsson 2002), assuming that the dead biomass becomes available at depths occupied by Greenland halibut.

\section{Temperature preference}

Greenland halibut occupied a narrow range of temperatures, between 1.3 and $2.7^{\circ} \mathrm{C}$, and spent the majority of their time in water temperatures of 2.0 to $2.5^{\circ} \mathrm{C}$. This temperature range was in agreement with that where Greenland halibut are most abundant in offshore waters $\left(0\right.$ to $6^{\circ} \mathrm{C}$ ) (Bowering \& Nedreaas 2000, Treble \& Jørgensen 2002). Considering that peak spawning temperatures in Davis Strait were estimated at 3.0 to $3.5^{\circ} \mathrm{C}$ (Jørgensen 1997b), the slightly cooler temperatures experienced by Greenland halibut in Cumberland Sound (the warmest bottom temperature measured by a satellite tag there was $2.7^{\circ} \mathrm{C}$, and CTD casts measured temperatures just above $0^{\circ} \mathrm{C}$ at $850 \mathrm{~m}$; Simonsen \& Treble 2003) suggest that the region is less suitable for spawning.

Although Greenland halibut have been shown to occupy waters below $2^{\circ} \mathrm{C}$ (Treble \& Jørgensen 2002, Treble 2011), only one of the fish (Fish 09) spent continual periods of time $(30 \%$; especially during the winter) at temperatures $\leq 2^{\circ} \mathrm{C}$. Low temperatures are thought to affect the metabolic and growth rates of adult Greenland halibut (Fonds et al. 1992, Patnaik et al. 1994); thus, movements to shallower waters dur- ing the winter might represent a strategy to reduce metabolic rates when ice is present and primary productivity decreases.

\section{Seasonal movements}

The vertical displacement of one fish (Fish 09) to shallower water potentially indicates that some Greenland halibut undertake seasonal movements out of the deep waters in Cumberland Sound. This movement could be driven by a factor associated with ice cover, as the fish moved to shallower water after ice had formed in January and moved back to the deeper water area when the ice started to recede and break-up in May. Considering that the second fish (Fish 08) that was tagged for $300 \mathrm{~d}$ did not undertake such a prominent movement to shallower water, this type of seasonal movement may be either a rare event or suggest that not all the Greenland halibut move to the shallower water for the ice-covered period. Because of the limited sample size, drawing conclusions about whether this is a typical behaviour is difficult.

The summer fishery is currently concentrated in the deep water area in the center of the Sound, and efforts to catch Greenland halibut in the shallow areas of the winter fishing grounds were unsuccessful during the summer (Young 2010). The fact that one of the 300 DAL Greenland halibut remained in deep water during the ice-covered period is also consistent with historic catches of these fish in deeper areas of the winter fishing grounds (DFO 2008b). Greenland halibut therefore appear to use a variety of residency-movement strategies with season. This potential variation in season-related movement tactics warrants further study as data will be critical for developing effective management plans for Cumberland Sound.

Why would Greenland halibut remain in deeper waters during the ice-free season and then move to shallower waters during the ice-cover season? One possibility could be to avoid predation by whales, in particular the beluga whale Delphinapterus leucas and narwhal Monodon monoceros, which are both thought to feed on Greenland halibut (Laidre \& Heide-Jørgensen 2005, Bluhm \& Gradinger 2008). Reports from Greenlandic waters have noted that the periodic disappearance of Greenland halibut often coincided with increased sightings of beluga whales (Anonymous 1993). A recent stable isotope study suggested that beluga whales do not feed on Greenland halibut during the spring and summer (M. Mar- 
coux unpubl.). This fits with our current understanding of the distributions of beluga whales and Greenland halibut within the Sound; they occupy separate areas during spring and summer (May to October) as Greenland halibut stay in deep water pockets in the central part of Cumberland Sound and beluga whales are mainly concentrated in Clearwater fiord within the Cumberland Sound management zone and along the west side of Cumberland Sound. However, their distributions may overlap during fall and winter when beluga whales gather over deeper areas around the margins of the growing land-fast ice, where Greenland halibut may be present (Kilabuk 1998, DFO 2008c).

Other studies have suggested that observed seasonal movements by Greenland halibut and other flatfishes are related to spawning and feeding (Jørgensen 1997b, Loher 2008, Loher \& Blood 2009). Although spawning by Greenland halibut typically occurs in water temperatures $>3^{\circ} \mathrm{C}$ (Jørgensen 1997b), occasional spawning has been observed in the fiords of northwestern Greenland, despite their low bottom temperatures that likely inhibit the maturation process (Templeman 1973). No evidence of spawning by Greenland halibut in Cumberland Sound has been reported (i.e. no ripe or spent males or females were found between 1990 and 1992; Pike 1994); however, the size of individuals suggested that adult females were present (Fadeev 1971, Pike 1994, Morgan et al. 2003). A final explanation could relate to seasonal movements of prey. Although data are not available for Cumberland Sound, prey abundance due to seasonal changes in primary production is expected to vary (Rysgaard et al. 1999) and may affect the movement patterns of predatory fishes.

\section{CONCLUSIONS}

Greenland halibut in Cumberland Sound appeared to be a deep dwelling species that spent the majority of their time near the sea bottom at depths greater than $900 \mathrm{~m}$ during the ice-free period. Detailed depth records found that individuals did not undertake diel movements into the upper water column or rapid vertical movements, which are expected behaviours if fish were feeding on pelagic prey. One Greenland halibut moved to shallower water following the occurrence of seasonal land-fast ice, returning to deep water for the ice-free period, while one individual remained in deep water throughout the same period. This indicates that Greenland halibut undertook different movement strategies across seasons within Cumberland Sound. This is an important consideration given that Cumberland Sound is currently divided into 2 management areas that manage Greenland halibut as 2 separate stocks. The mechanisms driving movement and residency of Greenland halibut are unknown but may be related to feeding and predator avoidance.

Acknowledgements. The authors thank A. MacNeil and J. Olin for help with statistical analyses and J. Weberschinke for help with data management. The authors also thank S. Kirchhoff, T. Gruninger, P. Tatchell, J. Cheater, M. Marcoux, E. Primeau, K. Ulrich, A. Young and D. Imrie for their help in the field. Funding and resources for this study were provided by Natural Sciences and Engineering Research Council of Canada and Canadian Foundation for Innovationfunded Ocean Tracking Network, Fisheries and Oceans Canada and the Government of Nunavut to ATF, NEH and $\mathrm{KJH}$, and University of Windsor scholarships to IP. This project was approved by the Hunters and Trappers Association of Pangnirtung and the Animal Care Committee at the University of Windsor.

\section{LITERATURE CITED}

Albert OT, Lambert Y, Vollen T, Freitas C, Heggenbakken L (2012) Distinguishing pelagic and demersal swimming of deepwater flatfish by recording of body angles. In: McKenzie J, Parsons B, Seitz A, Kopf RK, Mesa M, Phelps Q (eds) Advances in fish tagging and marking technology. Am Fish Soc Symp 76, Bethesda, MD

Allen MJ, Smith GB (1988) Atlas and zoogeography of common fishes in the Bering Sea and northeastern Pacific. NOAA Tech Rep 66. US Dept Commerce, Washington, DC

Anonymous (1993) Turbot (Greenland halibut). Fisheries and Oceans Canada, Communications Branch, Ottawa

Atkinson DB, Bowering WR (1987) The distribution and abundance of Greenland halibut, deepwater redfish, golden redfish, roundnose grenadier and roughhead grenadier in Davis Strait. Can Tech Rep Fish Aquat Sci 1578:1-29

Bailey RFJ, Able KW, Leggett WC (1977) Seasonal and vertical distribution and growth of juvenile and adult capelin (Mallotus villosus) in the St. Lawrence Estuary and western Gulf of St. Lawrence. J Fish Res Board Can 34:2015-2029

Bates D, Maechler M (2010) Linear mixed-effects models using S4 class in R. University of Wisconsin, Madison, WI, http://lme4.r-forge.r-project.org

Bjelland O, Bergstad OA, Skjæraasen JE, Meland K (2000) Trophic ecology of deep-water fishes associated with the continental slope of the eastern Norwegian Sea. Sarsia 85:101-117

Block BA, Dewar H, Blackwell SB, Williams TD and others (2001) Migratory movements, depth preferences, and thermal biology of Atlantic bluefin tuna. Science 293: 1310-1314

Bluhm BA, Gradinger R (2008) Regional variability in food availability for Arctic marine mammals. Ecol Appl 18: S77-S96 
Boje J (2002) Intermingling and seasonal migrations of Greenland halibut (Reinhardtius hippoglossoides) populations determined from tagging studies. Fish Bull 100: 414-422

> Botsford LW, Castilla JC, Peterson CJ (1997) The management of fisheries and marine ecosystems. Science 277: 509-515

$>$ Bowering WR (1984) Migrations of Greenland halibut, Reinhardtius hippoglossoides, in the Northwest Atlantic from tagging in the Labrador-Newfoundland region. J Northwest Atl Fish Sci 5:85-91

Bowering WR, Brodie WB (1995) Greenland halibut (Reinhardtius hippoglossoides): a review of the dynamics of its distribution and fisheries off eastern Canada and Greenland. In: Hopper AG (ed) Deep-water fisheries of the North Atlantic oceanic slope. Kluwer Academic, Dordrecht, p 113-160

Bowering WR, Lilly GR (1992) Greenland halibut (Reinhardtius hippoglossoides) off southern Labrador and northeastern Newfoundland (Northwest Atlantic) feed primarily on capelin (Mallotus villosus). Neth J Sea Res 29(1-3):211-222

> Bowering WR, Nedreaas KH (2000) A comparison of Greenland halibut (Reinhardtius hippoglossoides (Walbaum)) fisheries and distribution in the Northwest and Northeast Atlantic. Sarsia 85:61-76

Bristow P (1992) The illustrated encyclopedia of fishes. Chancellor Press, London

Brunnschweiler JM, Queiroz N, Sims DW (2010) Oceans apart? Short-term movements and behaviour of adult bull sharks Carcharhinus leucas in Atlantic and Pacific Oceans determined from pop-off satellite archival tagging. J Fish Biol 77:1343-1358

Christensen V, Guénette S, Heymans JJ, Walters CJ, Watson R, Zeller D, Pauly D (2003) Hundred-year decline of North Atlantic predatory fishes. Fish Fish 4:1-24

Crawford RE (1992) Life history of the Davis Strait Greenland halibut, with reference to the Cumberland Sound fishery. Can Manuscr Rep Fish Aquat Sci 2130:1-19

$>$ Davoren GK, Anderson JT, Montevecchi WA (2006) Shoal behaviour and maturity relations of spawning capelin (Mallotus villosus) off Newfoundland: demersal spawning and diel vertical movement patterns. Can J Fish Aquat Sci 63:268-284

> Dawe EG, Bowering WR, Joy JB (1998) Predominance of squid (Gonatus spp.) in the diet of Greenland halibut (Reinhardtius hippoglossoides) on the deep slope of the northeast Newfoundland continental shelf. Fish Res 36: $267-273$

de Groot SJ (1970) Some notes on an ambivalent behaviour of the Greenland halibut Reinhardtius hippoglossoides (Walb.) Pisces: Pleuronectiformes. J Fish Biol 2:275-279

$>$ Dennard ST, McMeans BC, Fisk AT (2009) Preliminary assessment of Greenland halibut diet in Cumberland Sound using stable isotopes. Polar Biol 32:941-945

> Dennard ST, MacNeil MA, Treble MA, Campana S, Fisk AT (2010) Hierarchical analysis of a remote, Arctic, artisanal longline fishery. ICES J Mar Sci 67:41-51

DFO (Department of Fisheries and Oceans) (2008a) Fishery management plan Greenland halibut NAFO Subarea 0, 2006-2008. Fisheries and Oceans Canada, Central and Arctic Region, Resource Management and Aboriginal Affairs, Winnipeg

DFO (Department of Fisheries and Oceans) (2008b) Cumberland Sound Greenland halibut (turbot) inshore fish- ery. DFO Can Sci Advis Sec Sci Rep 2008/40. Fisheries and Oceans Canada, Winnipeg

DFO, Department of Fisheries and Oceans (2008c) Fixed gear recommendations for the Cumberland Sound Greenland halibut fishery. DFO Can Sci Advis Sec Sci Rep 2008/11. Fisheries and Oceans Canada, Winnipeg

Dyck M, Warkentin PH, Treble MA (2007) A bibliography on Greenland halibut, Reinhardtius hippoglossoides (a.k.a. Greenland turbot) 1936-2005. Can Tech Rep Fish Aquat Sci 2683:1-309

Fadeev NS (1971) Biology and fisheries of the Pacific Ocean flatfishes. Dalizdat, Vladivostok (in Russian)

Fisk AT, Tittlemier SA, Pranschke JL, Norstrom RJ (2002) Using anthropogenic contaminants and stable isotopes to assess the feeding ecology of Greenland sharks. Ecology 83:2162-2172

> Fisk AT, Hoekstra PF, Gagnon JM, Duffe J and others (2003) Influence of habitat, trophic ecology and lipids on, and spatial trends of, organochlorine contaminants in Arctic marine invertebrates. Mar Ecol Prog Ser 262:201-214

Fonds M, Cronie R, Vethaak AD, Van Der Puyl P (1992) Metabolism, food consumption and growth of plaice (Pleuronectes platessa) and flounder (Platichthys flesus) in relation to fish size and temperature. Neth J Sea Res 29:127-143

Gibson RN (1997) Behaviour and the distribution of flatfishes. J Sea Res 37:241-256

Gibson RN (ed) (2005) Behaviour of flatfishes. In: Flatfishes: biology and exploitation. Blackwell Science, Oxford, p 213-239

Gundersen AC, Stenberg C, Fossen I, Lyberth B, Boje J, Jørgensen OA (2010) Sexual maturity cycle and spawning of Greenland halibut Reinhardtius hippoglossoides in the Davis Strait. J Fish Biol 77:211-226

Hilborn R, Branch TA, Ernst B, Magnusson A, Minte-Vera CV, Scheuerell MD, Valero JL (2003) State of the world's fisheries. Annu Rev Environ Resour 28:359-399

Humphries NE, Queiroz N, Dyer JRM, Pade NG and others (2010) Environmental context explains Lévy and Brownian movement patterns of marine predators. Nature 465: 1066-1069

> Jørgensen OA (1997a) Pelagic occurrence of Greenland halibut, Reinhardtius hippoglossoides (Walbaum), in West Greenland waters. J Northwest Atl Fish Sci 21:39-50

Jørgensen OA (1997b) Movement patterns of Greenland halibut, Reinhardtius hippoglossoides (Walbaum), at West Greenland, as inferred from trawl survey distribution and size data. J Northwest Atl Fish Sci 21:23-37

Kawabe R, Naito Y, Sato K, Miyashita K, Yamashita N (2004) Direct measurement of the swimming speed, tailbeat, and body angle of Japanese flounder (Paralichthys olivaceus). ICES J Mar Sci 61:1080-1087

Kilabuk P (1998) A study of Inuit knowledge of the Southeast Baffin beluga. Nunavut Wildlife Management Board, Iqaluit

> Kitagawa T, Kimura S, Nakata H, Yamada H (2004) Diving behavior of immature, feeding Pacific bluefin tuna (Thunnus thynnus orientalis) in relation to season and area: the East China Sea and the Kuroshio-Oyashio transition region. Fish Oceanogr 13:161-180

> Klages M, Muyakshin S, Soltwedel T, Arntz WE (2002) Mechanoreception, a possible mechanism for food fall detection in deep-sea scavengers. Deep-Sea Res I 49: 143-155

Laidre KL, Heide-Jørgensen MP (2005) Winter feeding 
intensity of narwhals (Monodon monoceros). Mar Mamm Sci 21:45-57

> Laidre KL, Heide-Jørgensen MP, Jørgensen OA, Treble MA (2004) Deep-ocean predation by a high Arctic cetacean. ICES J Mar Sci 61:430-440

Loher T (2008) Homing and summer feeding site fidelity of Pacific halibut (Hippoglossus stenolepis) in the Gulf of Alaska, established using satellite-transmitting archival tags. Fish Res 92:63-69

Loher T, Blood CL (2009) Seasonal dispersion of Pacific halibut (Hippoglossus stenolepis) summering off British Columbia and the US Pacific Northwest evaluated via satellite archival tagging. Can J Fish Aquat Sci 66: 1409-1422

Loher T, Seitz AC (2006) Seasonal migration and environmental conditions of Pacific halibut Hippoglossus stenolepis, elucidated from pop-up archival transmitting (PAT) tags. Mar Ecol Prog Ser 317:259-271

Marcoux M, McMeans BC, Fisk AT, Ferguson SH (in press) Composition and temporal variation in the diet of belugas in Cumberland Sound using stable isotopes. Mar Ecol Prog Ser

Morgan MJ, Bowering WR, Gundersen AC, Høines Å, Morin B, Smirnov O, Hjörleifsson E (2003) A comparison of the maturation of Greenland halibut (Reinhardtius hippoglossoides) from populations throughout the North Atlantic. J Northwest Atl Fish Sci 31:99-112

> Musyl MK, Domeier ML, Nasby-Lucas N, Brill RW and others (2011) Performance of pop-up satellite archival tags. Mar Ecol Prog Ser 433:1-28

NavSoft (2010) 2010 Nautical almanac. http://navsoft.com

> Orr DC, Bowering WR (1997) A multivariate analysis of food and feeding trends among Greenland halibut (Reinhardtius hippoglossoides) sampled in Davis Strait, during 1986. ICES J Mar Sci 54:819-829

Patnaik BK, Mahapatro N, Jena BS (1994) Ageing in fishes. Gerontology 40:113-132

> Pedersen SA, Riget F (1993) Feeding habits of redfish (Sebastes spp.) and Greenland halibut (Reinhardtius hippoglossoides) in West Greenland waters. ICES J Mar Sci 50:445-459

Pike DG (1994) The fishery for Greenland halibut (Reinhardtius hippoglossoides) in Cumberland Sound, Baffin Island, 1987-1992. Can Tech Rep Fish Aquat Sci 1924: $1-20$

R Development Core Team (2012) R: a language and environment for statistical computing, Version 2.14.1. R Foundation for Statistical Computing, Vienna. www.Rproject.org

Rayner NA, Parker DE, Horton EB, Folland CK and others (2003) Global analyses of sea surface temperature, sea ice, and night marine air temperature since the late nineteenth century. J Geophys Res 108, 4407, doi:10.1029/ 2002JD002670

Rysgaard S, Nielsen TG, Hansen BW (1999) Seasonal variation in nutrients, pelagic primary production and grazing in a high-Arctic coastal marine ecosystem, Young Sound, Northeast Greenland. Mar Ecol Prog Ser 179:13-25

Schaefer KM, Fuller DW (2004) Behavior of bigeye (Thunnus obesus) and skipjack (Katsuwonus pelamis) tunas within aggregations associated with floating objects in the equatorial eastern Pacific. Mar Biol 146:781-792

Schick RS, Loarie SR, Colchero F, Best BD and others (2008)

Editorial responsibility: Kenneth Sherman,

Narragansett, Rhode Island, USA
Understanding movement data and movement processes: current and emerging directions. Ecol Lett 11: 1338-1350

Schrank WE (2007) The ACIA, climate change and fisheries. Mar Policy 31:5-18

Seitz AC, Wilson D, Norcross BL, Nielsen JL (2003) Pop-up archival transmitting (PAT) tags: a method to investigate the migration and behavior of Pacific halibut Hippoglossus stenolepis in the Gulf of Alaska. Alsk Fish Res Bull 10:124-136

Serreze MC, Walsh JE, Chapin FS, Osterkamp T and others (2000) Observational evidence of recent change in the northern high-latitude environment. Clim Change 46: 159-207

Simonsen CS, Treble MA (2003) Tagging mortality of Greenland halibut, Reinhardtius hippoglossoides (Walbaum). J Northwest Atl Fish Sci 31:373-385

> Sims DW, Southall EJ, Richardson AJ, Reid PC, Metcalfe JD (2003) Seasonal movements and behaviour of basking sharks from archival tagging: no evidence of winter hibernation. Mar Ecol Prog Ser 248:187-196

> Sims DW, Southall EJ, Humphries NE, Hays GC and others (2008) Scaling laws of marine predator search behaviour. Nature 451:1098-1102

Sohn D, Ciannelli L, Duffy-Anderson JT (2010) Distribution and drift pathways of Greenland halibut (Reinhardtius hippoglossoides) during early life stages in the eastern Bering Sea and Aleutian Islands. Fish Oceanogr 19: 339-353

Templeman W (1973) Distribution and abundance of Greenland halibut, (Reinhardtius hippoglossoides (Walbaum)), in the Northwest Atlantic. ICNAF (International Commission for the Northwest Atlantic Fisheries) Res Bull 10:83-98

Teo SLH, Boustany A, Blackwell S, Walli A, Weng KC, Block BA (2004) Validation of geolocation estimates based on light level and sea surface temperature from electronic tags. Mar Ecol Prog Ser 283:81-98

Treble MA (2011) Report on Greenland halibut caught during the 2010 Trawl Survey in NAFO Division 0A. NAFO Sci Counc Res 11/17

Treble MA, Jorgensen OA (2002) Summary of results for Greenland halibut from trawl surveys conducted in NAFO Subareas 0 and 1 from $61^{\circ} \mathrm{N}$ to $74^{\circ} \mathrm{N}$ in 2001 . NAFO Sci Counc Res 02/60

Vilhjálmsson H (2002) Capelin (Mallotus villosus) in the Iceland-East Greenland-Jan Mayen ecosystem. ICES J Mar Sci 59:870-883

Vis ML, Carr SM, Bowering WR, Davidson WS (1997) Greenland halibut (Reinhardtius hippoglossoides) in the North Atlantic are genetically homogeneous. Can J Fish Aquat Sci 54:1813-1821

Vollen T, Albert OT (2007) Pelagic behavior of adult Greenland halibut (Reinhardtius hippoglossoides). Fish Bull 106:457-471

Wearmouth VJ, Sims DW (2009) Movement and behaviour patterns of the critically endangered common skate Dipturus batis revealed by electronic tagging. J Exp Mar Biol Ecol 380:77-87

Young A (2010) Development of the Cumberland Sound inshore summer fishery 2009. Government of Nunavut Department of Environment Fisheries and Sealing Division, Iqaluit 